\title{
Association between HLA system and susceptibility to Typhoid fever
}

\author{
N. Jusak*, F.M. Judajana*, E. Soewandojo**
}

\begin{abstract}
Abstrak
Penyakit infeksi berhubungan dengan gangguan imunitas. Tingkat respon ditentukan oleh beberapa faktor: intensitas infeksi, intensitas tanggap kebal pejamu dan faktor genetik. Sistem Human Leukocyte Antigens (HLA) memainkan peran penting pada interaksi antar sel dalam sistem imun. Hubungan antara HLA dan beberapa penyakit infeksi telah diketahui. Karena Indonesia mempunyai prevalensi demam tifoid yang paling tinggi, riset mengenai kemungkinan hubungan antara antigen HLA dan kepekaan terhadap demam tifoid telah dilaksanakan. Penentuan antigen HLA telah dilakukan dengan test mikrolimfositotoksisitas menggunakan Terasaki's dry tray. Tiga puluh sampel darah dikumpulkan dari pasien demam tifoid dengan kultur darah positif dari RS Dr Soetomo Surabaya. Sebagai kontrol, 30 sampel darah diambil dari orang yang tidak pernah mengalami demam lebih dari 5 hari dengan kultur urine dan feses negatif Salmonella spp. Analisis statistik dilakukan dengan tes Chi-square untuk $n>5$ dan tes Fisher's Exact untuk $n<5$ Hasil penelitian menunjukkan adanya hubungan antara antigen HLA dan kepekaan terhadap demam tifoid. Hal tersebut membuktikan adanya predisposisi genetik, yaitu seseorang dengan antigen HLA B7 dan DRIO cenderung mudah terkena demam tifoid, sementara individu dengan antigen HLA BI8 mempunyai suatu faktor protektif untuk mencegah demam tifoid.
\end{abstract}

\begin{abstract}
Infectious Disease are associated with impaired immunity. The level of response is determined by several factors: intensity of infections, intensity of host immune response, and genetic factor. Human Leukocyte Antigens (HLA) system plays an important role in cell-to-cell interaction in the immune system. Association between HLA and some infectious diseases has been established. Because Indonesia has the highest prevalence of typhoid fever, a research on the possible association between HLA antigen and susceptibility to typhoid fever was carried out. HLA antigen were determined by microlymphocytotoxicity test using Terasaki's dry tray. Thirty blood samples were collected from typhoid fever patients with positive blood culture taken from Dr. Soetomo Hospital Surabaya. As a control 30 blood samples were taken from subjects who had never had a prolonged fever more than 5 days, and negative urine and faeces culture for Salmonella spp. Statictical analysis were done by Chi-square test for $n>5$ and Fisher's Exact test for $n<5$. Results indicated that there was an association between HLA antigen and susceptibility to typhoid fever. This proved the existance of genetic predisposition in which individuals with HLA antigen B7 and DRIO are prone to get typhoid fever, whereas individuals with HLA antigen B18 has a protective factor to prevent typhoid fever.
\end{abstract}

* Department Clinical Pathology

** Department Internal Medicine, Airlangga University, Surabaya, Indonesia 